\title{
Pengaruh kombinasi vitamin c dan vitamin e terhadap Kadar malondialdehid plasma pasien diabetes mellitus tipe 2
}

\author{
Yade Kurnia Yasin', Martha I Kartasurya², RA Kisdjamiatun RMD ${ }^{3}$
}

\begin{abstract}
Background: Malondialdehyde (MDA) levels produced by oxidative stress in type 2 diabetes mellitus (T2DM) is higher than in non diabetes patients. Vitamin $C$ and $E$ inhibit oxidative stress and MDA production. The purpose of this study was to prove the effects of combined vitamin $C$ and vitamin $E$ on MDA plasma levels in T2DM patients.

Methods: This double blind randomized pre post test control group design was carried out on 35 patients with T2DM without complication (age 40-60 yr) in Makassar. The treatment group $(n=18)$ received vitamin $C 250 \mathrm{mg} /$ day plus vitamin E 400 IU/day and the control group $(n=17)$ received placebo (seaweed powder $250 \mathrm{mg}$ ), for six weeks. Vitamin $C$ was consumed before meal and vitamin E after meal. MDA levels were measured before and after supplementation by using TBARs method. Food intake and activity were derived from 24-hour recall method.

Results: There was no different on MDA levels at baseline ( $p=0.151)$. At the end of the study, MDA levels increased in control group $(5.8 \pm 2.74$ to $7.2 \pm 3.00 \mathrm{nmol} / \mathrm{ml} ; \mathrm{p}=0.044)$ but not in the treatment group $(7.2 \pm 2.88$ to $7.7 \pm 2.02 \mathrm{nmol} / \mathrm{ml} ; \mathrm{p}=0.490)$. There was no difference in MDA alteration between the goups $(p=0.316)$. There was no different in MDA levels at the end of the study $(p=0.061)$ and confirmed after controlling the confounding variables: vitamin E intake and fasting blood glucose ( $p=0.809)$.

Conclusion: Combined vitamin C $250 \mathrm{mg}$ and vitamin E 400 IU for 6 weeks did not reduce MDA levels, but inhibit MDA production in T2DM patients.
\end{abstract}

Keywords: Malondialdehyde, Vitamin C, Vitamin E, Type 2 Diabetes Mellitus

\begin{abstract}
ABSTRAK
Latar Belakang: Kadar malondialdehid (MDA) sebagai hasil dari stres oksidatif akibat hiperglikemia, pada pasien diabetes mellitus tipe 2 (DMT2) lebih tinggi dibandingkan dengan pasien tanpa diabetes. Vitamin C dan vitamin E dapat menghambat reaksi stres oksidatif dan produksi MDA. Tujuan penelitian ini adalah membuktikan pengaruh kombinasi vitamin $C$ dan vitamin E terhadap kadar MDA plasma pasien DMT2.

Metode: Penelitian dengan rancangan double blind randomized pre post test control group ini dilakukan pada 35 pasien diabetes tanpa komplikasi, umur 40-60 tahun di Makassar. Kelompok perlakuan (n=18) mendapatkan vitamin C 250 mg/hari dan vitamin E 400 IU/hari selama 6 minggu. Kelompok kontrol ( $n=17)$ mendapatkan plasebo yang berisi bubuk rumput laut 250 mg. Vitamin C dikonsumsi sebelum makan dan vitamin E setelah makan. Kadar MDA diukur sebelum dan setelah suplementasi menggunakan metode TBARs. Asupan makanan dan aktivitas fisik diperoleh dari recall 24 jam.

Hasil: Tidak ada perbedaan rerata kadar MDA sebelum suplementasi antara kedua kelompok ( $p=0,151)$. Setelah suplementasi, rerata kadar MDA meningkat pada kelompok kontrol $(5,8 \pm 2,74$ menjadi 7,2 $23,00 \mathrm{nmol} / \mathrm{ml} ; \mathrm{p}=0,044)$ sedangkan kelompok

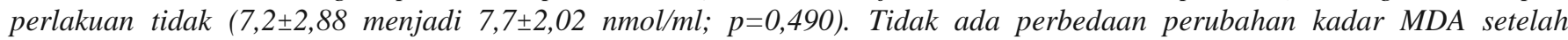
suplementasi $(p=0,316)$ antara kedua kelompok. Tidak ada perbedaan kadar MDA di akhir suplementasi ( $p=0,610)$ serta sebelum dan setelah $(p=0,809)$ dikontrol variabel perancu (asupan vitamin E dan glukosa darah puasa) antara kedua kelompok. Simpulan: Kombinasi vitamin C $250 \mathrm{mg}$ dan vitamin E $400 \mathrm{IU}$ selama 6 minggu tidak menurunkan, namun menghambat peningkatan kadar MDA plasma pasien DMT2.
\end{abstract}

Kata kunci: Malondialdehid, Vitamin C, Vitamin E, Diabetes Mellitus Tipe 2

\section{PENDAHULUAN}

Diabetes mellitus (DM) adalah penyakit kronik progresif yang ditandai dengan peningkatan kadar glukosa darah (hiperglikemia) akibat penurunan sekresi dan atau aktivitas insulin, yang dilatarbelakangi oleh resistensi insulin. ${ }^{1}$ Pada DM terjadi abnormalitas

1. Poltekkes Kemenkes Gorontalo

2. Bagian Gizi Kesehatan Masyarakat, Fakultas Kesehatan Masyarakat, Universitas Diponegoro

3. Magister Ilmu Biomedik, Fakultas Kedokteran, Universitas Diponegoro metabolisme karbohidrat, lemak, dan protein akibat kekurangan insulin pada jaringan target. ${ }^{1}$ Diabetes mellitus juga ditandai dengan terjadinya stres oksidatif, inflamasi, dan disfungsi sel $\beta$ pankreas. Penyakit ini merupakan salah satu penyakit yang menyebabkan peningkatan risiko kematian dan penurunan kualitas hidup akibat berbagai komplikasi serius. ${ }^{2}$ Faktor risiko terjadinya diabetes mellitus sangat beragam dan saat ini yang paling umum diderita masyarakat adalah Diabetes Mellitus Tipe 2 (DMT2).

Prevalensi diabetes mellitus semakin meningkat di hampir semua negara. Organisasi Kesehatan Dunia (WHO) memperkirakan bahwa dari 
seluruh kasus diabetes di dunia, 90\% diantaranya merupakan kasus DMT2. Statistik terbaru oleh International Diabetes Federation (IDF) memperlihatkan bahwa prevalensi global DM yang diperkirakan 382 juta pada tahun 2013, akan meningkat menjadi 592 juta pada tahun $2035 .{ }^{3}$ Prevalensi nasional DM di Indonesia menurut Riskesdas 2007, berdasarkan diagnosis tenaga kesehatan dan gejala adalah $1,1 \%{ }^{4}$ Prevalensi DM di tingkat provinsi Sulawesi Selatan (Sulsel) mencapai $0,8 \%$ dan di kota Makassar menunjukkan angka $0,4 \%, 4,5$ meskipun jauh dari prevalensi nasional namun pola makan dan gaya hidup orang Makassar dapat mengarahakan pada kejadian DM. Pola makan masyarakat Makassar, berupa konsumsi tinggi makanan manis, makanan berlemak, jeroan, konsumsi rendah sayuran dan buah $(<5$ porsi per hari), kurang melakukan aktivitas fisik dan memiliki kebiasaan merokok menjadi faktor risiko yang dapat memicu gangguan pada metabolisme tubuh dalam menggunakan insulin dan meningkatkan kejadian DMT2 serta menjadi faktor meningkatnya aktivitas oksidasi dalam tubuh, yang dipengaruhi oleh keadaan hiperglikemia. ${ }^{5}$

Hiperglikemia adalah penyebab utama kerusakan jaringan pada DM, baik melalui perubahan akut berulang dalam metabolisme glukosa seluler atau melalui akumulasi jangka panjang biomolekul terglikasi dan keadaan stress oksidatif. ${ }^{6,7}$ Salah satu mekanisme patogenik yang meningkatkan risiko terjadinya diabetes dan komplikasinya adalah ketidakseimbangan antara pro-oksidan dan antioksidan. Hal ini merupakan awal kerusakan oksidatif yang dikenal sebagai stres oksidatif. ${ }^{8,9}$

Stres osidatif dan radikal bebas terbentuk secara tidak proporsional pada diabetes oleh autooksidasi glukosa, glikasi non-enzimatik protein, dan degradasi oksidatif dari protein terglikasi, serta lemak tak jenuh dalam membran plasma dan protein. Selanjutnya, radikal bebas akan meningkatkan produksi malondialdehid (MDA) ${ }^{10}$ Konsentrasi MDA dalam plasma meningkat pada diabetes mellitus, dan menengahi beberapa proses proinflamasi dan proatherogenik sehingga ditemukan dalam plak aterosklerotik yang dipromosikan oleh diabetes. ${ }^{11,12}$ Beberapa penelitian menyatakan bahwa terjadi peningkatan kadar MDA pada kelompok DM dibandingkan dengan kelompok non DM. ${ }^{13-17}$

Vitamin C dan vitamin E diklaim sebagai antioksidan yang berfungsi untuk mengurangi stres oksidatif dan ROS, akibat keadaan hiperglikemia dan disfungsi sel $\beta$ pankreas, serta meningkatkan aktivitas enzim antioksidan seperti SOD dan GSH. ${ }^{18}$ Vitamin C (asam askorbat) secara struktural mirip dengan glukosa dan dapat menggantikan gugus glukosa ke dalam banyak reaksi kimia, dengan demikian efektif untuk mencegah glikosilasi non-enzimatik protein. ${ }^{19}$ Asam askorbat dapat memutus reaksi radikal yang dihasilkan melalui lipoperoksida dengan bereaksi secara langsung pada fase cair dengan radikal lipid peroksida, sehingga menekan produksi MDA. ${ }^{20}$ Vitamin E ( $\alpha$-tokoferol) mereduksi radikal bebas lipid lebih cepat daripada oksigen, efektif secara moderat mengakhiri rantai reaksi singlet oxygen, serta paling efektif untuk mengakhiri rantai reaksi peroksidasi lipid dan produksi MDA dalam membran sel. ${ }^{20}$

Penggunaan suplementasi vitamin $\mathrm{C}$ dan atau vitamin $\mathrm{E}$ dengan dosis tunggal dengan durasi pemberian yang bervariasi pada beberapa penelitian, secara signifikan dapat menurunkan kadar MDA pasien DMT2. ${ }^{21-23}$ Penggunaan kombinasi vitamin $\mathrm{C}$ dan vitamin E merupakan salah satu upaya untuk menghindari pemberian dosis terlalu tinggi, selain itu karena vitamin $\mathrm{E}$ dapat berubah menjadi senyawa radikal pada oksidasi maka diperlukan vitamin $\mathrm{C}$ untuk regenerasi ${ }^{20}$ Peran suplementasi vitamin $\mathrm{C}$ dan vitamin E sebagai antioksidan dalam pengelolaan klinis diabetes merupakan salah satu upaya pencegahan alternatif untuk menghambat progresivitas diabetes menjadi lebih parah dan mencegah terjadinya komplikasi yang mengarah kepada kardiovaskular ataupun penyakit lainnya. Tujuan penelitian ini adalah membuktikan pengaruh kombinasi vitamin $\mathrm{C}$ dan vitamin $\mathrm{E}$ terhadap perubahan kadar MDA plasma pasien DMT2.

\section{BAHAN DAN METODE}

Penelitian ini menggunakan rancangan double blind randomized pre post test controlled group. Variabel bebas penelitian adalah suplementasi vitamin C $250 \mathrm{mg} /$ hari dan vitamin E $400 \mathrm{IU} / \mathrm{hari}$, variabel terikat adalah kadar MDA plasma, variabel antara adalah kadar GDP, dan variabel perancu adalah asupan berupa total kebutuhan energi, protein, asupan karbohidrat, lemak, PUFA, asam lemak trans (ALT), serat, vitamin C, vitamin E, dan aktivitas fisik. Populasi terjangkau adalah pasien rawat jalan DMT2 di Puskesmas Makkasau Makassar dan subjek penelitian adalah yang memenuhi kriteria inklusi yaitu terdiagnosa DMT2 tanpa komplikasi, berumur 40-60 tahun, berdomisili di Makassar, tidak sedang mengkonsumsi suplementasi lain, obat diuretik, atau antasida, tidak sedang menjalani terapi insulin, dan bersedia menjadi subjek penelitian dengan mengisi informed consent. Kriteria ekslusi adalah mendapat terapi insulin dan mengkonsumsi suplementasi lain, kepatuhan suplementasi $<80 \%$ dan merokok lebih dari 20 batang/hari. Penelitian dilakukan di Puskesmas Makkasau Makassar pada bulan Mei hingga Juli 2014.

Subjek dibagi secara acak menjadi 2 kelompok yaitu kelompok perlakuan yang diberi suplementasi vitamin C 250 mg dan vitamin E 400 IU, dan kelompok 
kontrol yang diberi plasebo berisi bubuk rumput laut $250 \mathrm{mg} / \mathrm{kapsul}$ (Energi=0,71 kkal; $\mathrm{KH}=0,29 \mathrm{~g}$; serat $=0,29 \mathrm{~g}$ ), selama masing-masing 6 minggu. Plasebo diberikan dengan dosis $250 \mathrm{mg}$, jauh dari kebutuhan harian untuk serat pangan penderita diabetes yaitu 25 gram per hari, sehingga tidak akan menggangu pengukuran akhir variabel penelitian. Bentuk, ukuran dan warna antara kapsul vitamin dan plasebo sama. Kapsul vitamin C dikonsumsi sebelum makan dan vitamin E setelah makan. Selain mengkonsumsi suplemen yang diberikan, subjek tetap mengkonsumsi obat diabetes yang diresepkan oleh dokter. Pemberian suplementasi tidak dilakukan serentak pada semua subjek, sehingga terdapat beberapa subjek yang masa suplementasinya berakhir pada 3 pekan pertama bulan puasa Ramadhan. Semua subjek penelitian mendapatkan edukasi gizi di awal penelitian.

Data karakteristik (umur, jenis kelamin, antropometri, riwayat merokok) diperoleh dari hasil wawancara. Data asupan diperoleh dari recall 24 jam dan dianalisis menggunakan Nutrisurvey. Data aktivitas fisik juga diperoleh dari recall 24 jam dan dihitung dengan Physical Activity Level (PAL). Data asupan dan aktivitas fisik merupakan variabel perancu yang selanjutnya akan dikontrol melalui analisis statistik uji korelasi dan multivariat.

Kadar MDA plasma diukur sebelum dan setelah suplementasi. Pengambilan darah dilakukan setelah subjek menjalani puasa selama minimal 8 jam dan disimpan dalam bentuk plasma di Klinik Prodia Makassar. Pemeriksaan kadar MDA plasma dikerjakan di Laboratorium Pangan dan Gizi, PAU Universitas Gajah Mada Yogyakarta, diukur menggunakan metode TBARs. Analisis MDA menggunakan reagen $\mathrm{H}_{3} \mathrm{PO}_{4}$ sebanyak $0,75 \mathrm{ml}$; TBA sebanyak $0,25 \mathrm{ml}$; aqubides sebanyak 0,45 ml dan dicampur dengan Standart Tetra Ethoxy Propane dan sampel 0,05 ml. Hasil campuran tersebut lalu dimasukkan ke dalam penangas air dengan suhu $\pm 100^{\circ} \mathrm{C}$ selama 60 menit dan didinginkan serta disaring menggunakan Sep-Pak catridges C18. Hasilnya dibaca menggunakan spektofotometer dengan panjang gelombang $532 \mathrm{~nm}$ dan diinterpretasikan dengan satuan $\mathrm{nmol} / \mathrm{ml}$.

Analisis data diolah menggunakan SPSS. Data deskriptif menampilkan rerata dan standar deviasi dari data karakteristik, data asupan, dan data hasil pemeriksaan kadar MDA subjek. Uji normalitas data menggunakan Shapiro Wilk. Analisis uji beda antar kelompok menggunakan uji independent sample t-test dan Mann Whitney, uji beda sebelum dan setelah pada kelompok menggunakan uji paired t-test, dan uji beda data kategorik menggunakan uji Chi square dan
Kolmogorov Smirnov. Uji korelasi menggunakan uji Pearson dengan nilai signifikansi $p<0,05$ dan uji multivariat menggunakan uji regresi linear untuk melihat pengaruh antara variabel terikat dan variabel perancu.

Penelitian ini telah mendapatkan persetujuan dari Komisi Etik Penelitian Kesehatan (KEPK) Fakultas Kedokteran Universitas Diponegoro dan RSUP dr. Kariadi Semarang dengan ethical clearance dengan nomor 295/EC/FK-RSDK/2014. Semua informasi dan data yang dikumpulkan dari subjek penelitian dijamin kerahasiaannya dan hanya digunakan untuk keperluan ilmiah.

\section{HASIL}

Penelitian dimulai dengan mengumpulkan data dan skrining pada 80 orang yang tercatat sebagai pasien DMT2 tanpa komplikasi. Diperoleh 39 orang dari hasil skrining yang memenuhi kriteria inklusi dan bersedia menjadi reseponden serta mengikuti rangkaian pemeriksaan pre test dan suplementasi selama 6 minggu. Di akhir suplementasi, terdapat satu orang dari kelompok perlakuan dan tiga orang dari kelompok kontrol yang drop out dari penelitian karena tidak mengikuti pemeriksaan setelah suplementasi (post test), sehingga diperoleh subjek penelitian sebanyak 18 orang kelompok perlakuan dan 17 orang pada kelompok kontrol (Gambar 1).

Tabel 1 menunjukkan data karateristik subjek meliputi umur, jenis kelamin, IMT, lingkar pinggang, lingkar panggul, subjek yang suplementasinya pada bulan Ramadhan, riwayat merokok, dan kadar glukosa darah puasa (GDP) sebelum dan setelah suplementasi. Perbedaan hasil tidak ditemukan pada data karakteristik antara kelompok perlakuan dan kontrol.

Tabel 2 menunjukkan data asupan dan aktivitas fisik dalam bentuk Physical Activity Level (PAL) selama penelitian. Asupan subjek tidak menunjukkan perbedaan untuk total kebutuhan energi, protein, asupan karbohidrat, lemak, PUFA, serat, vitamin C, dan vitamin E. Perbedaan ditemukan pada asupan asam lemak trans (ALT) $(p=0,017)$. Asupan ALT subjek penelitian diperoleh dari konsumsi makanan olahan kue menggunakan margarin, minyak (shortening), biskuit, santan, daging, dan susu, konsumsi ALT juga meningkat setelah memasuki bulan Ramadhan pada beberapa subjek. Setelah dilakukan uji korelasi dan multivariat diperoleh hasil bahwa asupan dan aktivitas tidak memiliki hubungan dan pengaruh terhadap kadar MDA setelah suplementasi. 


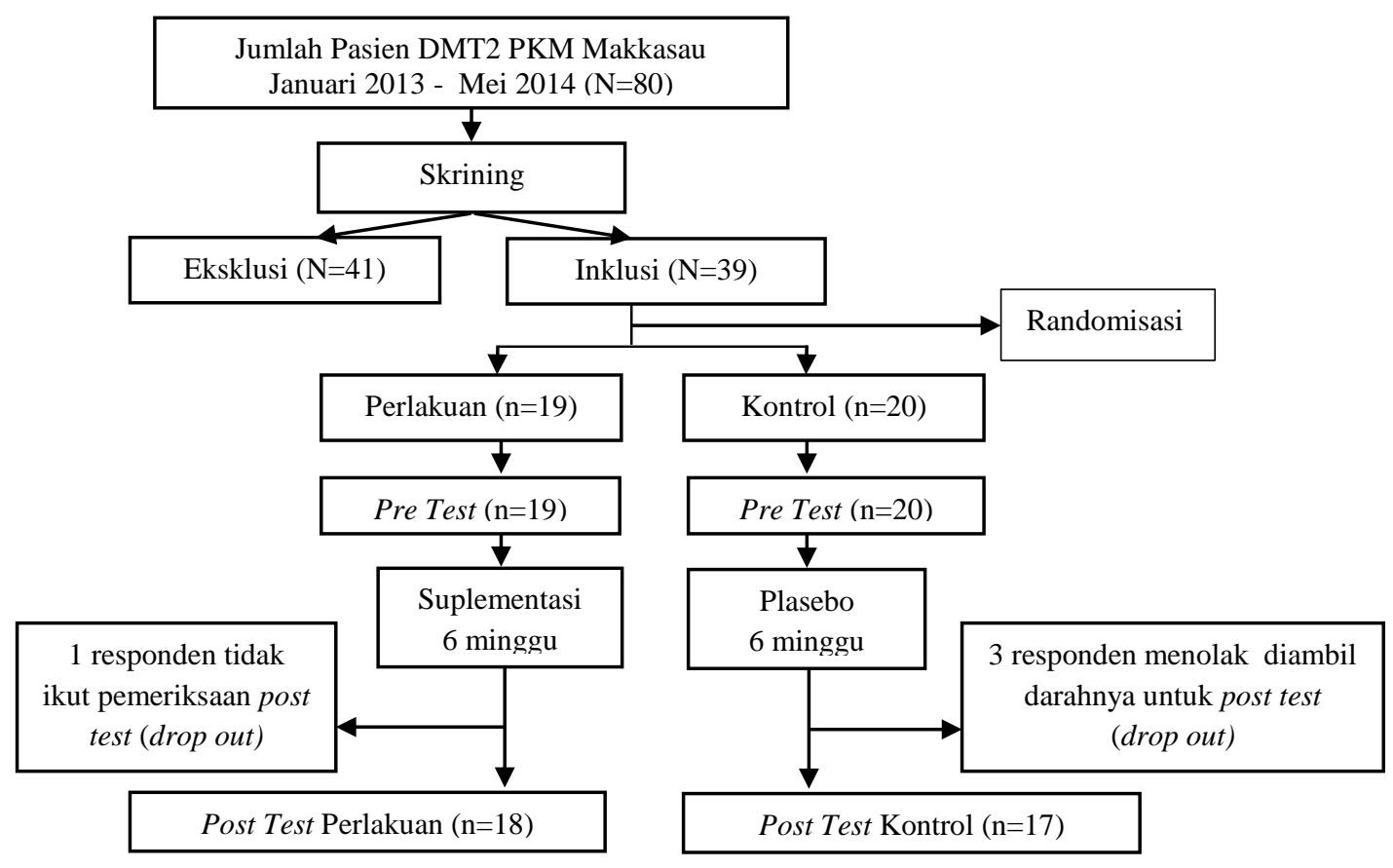

Gambar1. Bagan Consort

Tabel 1. Karakteristik Subjek Kelompok Perlakuan dan Kontrol (Mean \pm SD)

\begin{tabular}{lccc}
\hline \multirow{2}{*}{ Variabel } & \multicolumn{2}{c}{ Kelompok } & Nilai \\
\cline { 2 - 3 } & Perlakuan $(\mathbf{n}=\mathbf{1 8})$ & Kontrol (n=17) & $\boldsymbol{p}$ \\
\hline Umur (tahun) & $51 \pm 4,67$ & $51,7 \pm 5,10$ & $0,672^{\mathrm{a}}$ \\
Jenis Kelamin (L/P) (n) & $5 / 13$ & $3 / 14$ & $0,476^{\mathrm{c}}$ \\
IMT (kg/m ${ }^{2}$ & $25,3 \pm 3,83$ & $25,0 \pm 4,48$ & $0,832^{\mathrm{a}}$ \\
Lingkar Pinggang (cm) & $90,3 \pm 10,71$ & $91,0 \pm 11,51$ & $0,766^{\mathrm{b}}$ \\
Lingkar Panggul (cm) & $95,9 \pm 7,84$ & $94,5 \pm 9,44$ & $0,428^{\mathrm{b}}$ \\
Suplementasi bulan Ramadhan (n) & $8(44,4 \%)$ & $5(29,4 \%)$ & $0,358^{\mathrm{c}}$ \\
Riwayat merokok (n) & $4(22,2 \%)$ & $4(23,4 \%)$ & $0,927^{\mathrm{c}}$ \\
GDP (mg/dL) & & & \\
$\quad$ Sebelum & $200,3 \pm 67,38$ & $205,9 \pm 66,64$ & $0,806^{\mathrm{a}}$ \\
\multicolumn{1}{c}{ Setelah } & $210,2 \pm 67,29$ & $214,6 \pm 78,42$ & $0,859^{\mathrm{a}}$ \\
\hline${ }^{\mathrm{a}}$ Independent Sample t-test & ${ }^{\mathrm{b}}$ Mann Whitney ${ }^{\mathrm{c}}$ Chi Square &
\end{tabular}

Tabel 2. Perbedaan Asupan Zat Gizi Harian dan Physical Activity Level (PAL) Selama Penelitian antara Kelompok Perlakuan dan Kontrol

\begin{tabular}{lccr}
\hline \multirow{2}{*}{ Variabel } & \multicolumn{2}{c}{ Kelompok } & \multirow{2}{*}{ Nilai $\boldsymbol{p}$} \\
\cline { 2 - 3 } & Perlakuan (n=18) & Kontrol (n=17) & \\
\cline { 2 - 3 } & Rerata \pm SD & Rerata \pm SD & $0,526^{\mathrm{a}}$ \\
\hline \% TKE & $92,5 \pm 28,38$ & $86,3 \pm 29,07$ & $0,607^{\mathrm{a}}$ \\
\% TKP & $91,6 \pm 26,54$ & $86,1 \pm 36,48$ & $0,346^{\mathrm{a}}$ \\
Asupan KH (\%) & $55,5 \pm 5,93$ & $58,5 \pm 11,84$ & $0,259^{\mathrm{a}}$ \\
Asupan Lemak (\%) & $29,8 \pm 6,68$ & $26,4 \pm 10,20$ & $0,980^{\mathrm{a}}$ \\
Asupan PUFA (\%) & $21,8 \pm 8,54$ & $21,8 \pm 9,36$ & $\mathbf{0 , 0 1 7 ^ { \mathbf { a } }}$ \\
Asupan ALT (g) & $6,0 \pm 3,08$ & $3,7 \pm 2,81$ & $0,433^{\mathrm{a}}$ \\
Asupan Serat (g) & $6,6 \pm 2,00$ & $6,1 \pm 2,23$ & $0,940^{\mathrm{a}}$ \\
Asupan Vit.C (mg) & $26,6 \pm 21,82$ & $27,3 \pm 24,69$ & $0,716^{\mathrm{a}}$ \\
Asupan Vit. E (eq) & $3,5 \pm 1,79$ & $3,2 \pm 2,11$ & $0,343^{\mathrm{a}}$ \\
(mg) & $1,74 \pm 0,25$ & $1,67 \pm 0,12$ & \\
PAL & & &
\end{tabular}


Rerata kadar MDA sebelum suplementasi tidak berbeda antara kelompok perlakuan dan kontrol $(p=0,151)$. Setelah suplementasi, rerata kadar MDA meningkat pada kontrol $(5,8 \pm 2,74$ menjadi $7,2 \pm 3,00$ $\mathrm{nmol} / \mathrm{ml} ; \quad p=0,044)$ sedangkan pada kelompok perlakuan tidak terdapat peningkatan $(7,2 \pm 2,88$ menjadi $7,7 \pm 2,02 \mathrm{nmol} / \mathrm{ml} ; p=0,490)$. Tidak ada perbedaan perubahan setelah suplementasi $(p=0,316)$ antara kedua kelompok. Setelah dilakukan uji multivariat untuk mengontrol variabel perancu diperoleh hasil bahwa tidak ada perbedaan kadar MDA di akhir suplementasi $(p=0,610)$ serta sebelum dan setelah $(p=0,809)$ dikontrol variabel perancu (asupan vitamin E dan glukosa darah puasa) antara kedua kelompok.

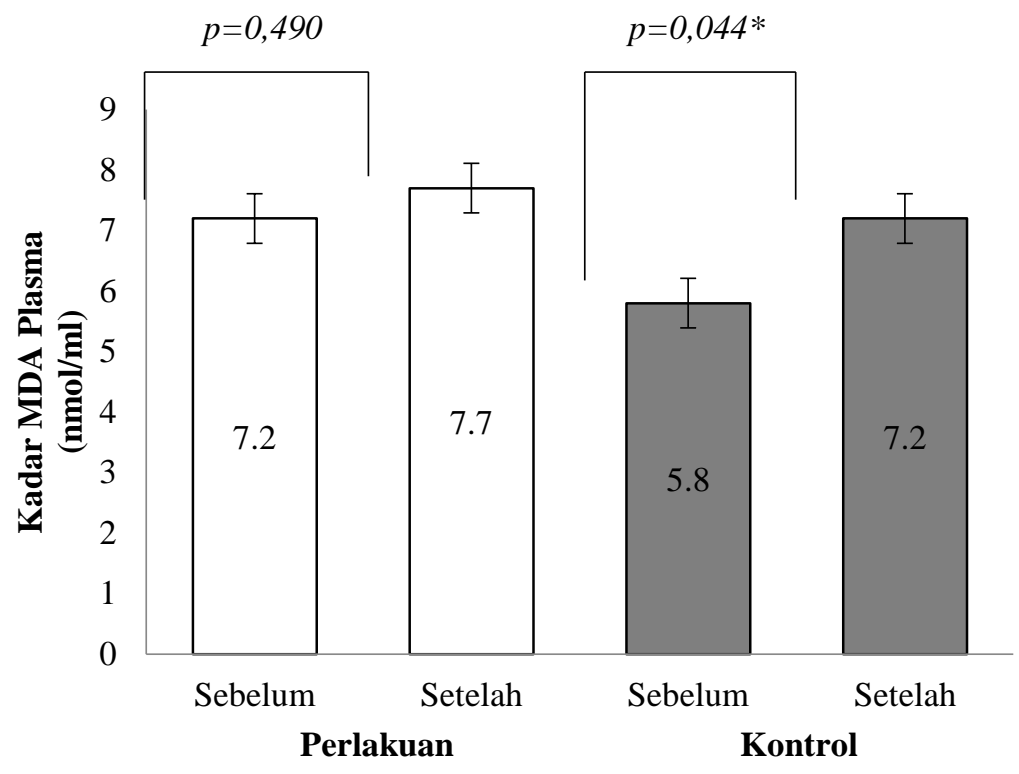

$* p<0,05$

Gambar 2. Perubahan Kadar MDA Sebelum dan Setelah Suplementasi pada Kelompok Perlakuan dan Kontrol

\section{PEMBAHASAN}

Setelah dilakukan suplementasi selama 6 minggu pada 18 orang kelompok perlakuan diperoleh hasil bahwa suplementasi vitamin C $250 \mathrm{mg}$ dan vitamin E 400 IU tidak dapat menurunkan kadar MDA plasma pasien DMT2, namun dapat menghambat peningkatan kadar MDA dibandingkan kelompok kontrol yang mendapatkan plasebo. Vitamin C berperan sebagai inhibitor enzim aldose reduktase sehingga meminimalisasi pembentukan AGEs dan menekan produksi $\mathrm{MDA},{ }^{8}$ dan vitamin $\mathrm{E}$ berperan menghambat reaksi rantai radikal lipid. ${ }^{24}$ Keduanya mampu bekerja bersama menghambat reaksi oksidasi, dengan mengaktifkan sejumlah antioksidan enzimatik lain seperti SOD dan $\mathrm{GSH}^{21,23}$ namun akibat kondisi hiperglikemia yang terjadi terus menerus menyebabkan produksi peroksidasi lipid meningkat, sehingga antioksidan tubuh tidak mampu mengimbangi peningkatan oksidasi ini. Peningkatan kadar MDA pada subjek penelitian sejalan dengan keadaan hiperglikemia yang dialami. Berdasarkan uji korelasi dan pengaruh menunjukkan bahwa ada hubungan dan pengaruh kadar GDP terhadap kadar MDA setelah suplementasi $(p=0,001)$. Tingginya kadar GDP diikuti dengan tingginya kadar MDA, hal ini terjadi akibat peningkatan hiperglikemia dapat mempromosikan peningkatan peroksidasi lipid, sehingga meningkatkan produksi MDA.

Peningkatan SOD tetap diikuti dengan peningkatan produksi anion superoksida radikal $\left(\bullet \mathrm{O}_{2}\right)$ dan hidrogen peroksida $\left(\mathrm{H}_{2} \mathrm{O}_{2}\right)$ karena kadar glukosa yang tinggi dalam darah atau tingkat inflamasi kronis pada diabetes seperti lesi pada sel $\beta$ pankreas. ${ }^{25}$ Beberapa penelitian yang mengukur aktivitas antioksidan untuk melihat kemampuannya menahan proses stres oksidatif, ternyata memperlihatkan hasil bahwa konsentrasi dan aktivitas antioksidan yang tinggi dalam tubuh tidak secara simultan dapat menekan produksi stres oksidatif. ${ }^{25,26}$ Pada penelitian ini, tidak dilakukan pengukuran terhadap aktivitas antioksidan enzimatik seperti SOD dan GSH sehingga tidak diketahui seberapa besar peningkatan aktivitas antioksidan enzimatik tubuh oleh suplementasi vitamin $\mathrm{C}$ dan vitamin $\mathrm{E}$.

Kadar MDA yang tinggi di dalam tubuh juga disebabkan karena di dalam mitokondria dan membran mikrosomal mengandung asam lemak tak jenuh ganda 
(PUFA) dengan jumlah yang relatif besar. Kehadiran 3 atau lebih ikatan rangkap cenderung lebih peka terhadap serangan radikal bebas mengakibatkan peroksidasi lipid yang tinggi, dan konsentrasi antioksidan vitamin $\mathrm{C}$ dan vitamin $\mathrm{E}$ dalam tubuh tidak mampu mengimbangi peningkatan produksi peroksidasi lipid tersebut. ${ }^{27}$ Rata-rata subjek penelitian ini memiliki asupan PUFA yang tinggi dan memiliki kadar MDA yang tinggi, namun setelah diuji statistik, menunjukkan bahwa tidak ada hubungan antara asupan PUFA dengan kadar MDA setelah suplementasi. Asupan ALT yang berbeda antara kelompok perlakuan dan kontrol juga menunjukkan tidak ada hubungan dan pengaruh terhadap kadar MDA. Asam lemak trans bisa saja tidak berdampak langsung pada kadar MDA, namun pada marker oksidasi yang lain seperti LDLox atau nitric oxide yang tidak diteliti pada penelitian ini. Penelitian pada hewan coba non-DM yang diberikan ALT 10\% menunjukkan hasil bahwa terjadi peningkatan kadar GDP, nekrosis sel $\beta$ pankreas, dan peroksidasi lipid yang ditandai dengan produksi NO yang meningkat, namun pada penelitian ini tidak mengukur kadar MDA. ${ }^{28}$

Tingkat kebutuhan vitamin $\mathrm{C}$ dan vitamin $\mathrm{E}$ dalam tubuh meningkat akibat kurangnya asupan vitamin, sehingga vitamin $\mathrm{C}$ yang masuk digunakan untuk kebutuhan tubuh terlebih dahulu, dibanding bertindak sebagai antioksidan melawan stres oksidatif. Hilsalkar et al dalam penelitiannya menyebutkan bahwa status vitamin $\mathrm{C}$ yang rendah pada diabetes dikarenakan tingkat turnover yang lebih tinggi dari asam askorbat diikuti oksidasi yang meningkat dalam bentuk dehidroaskorbat teroksidasi. ${ }^{29}$

Mekanisme lain yang dapat menjelaskan hal ini adalah terganggunya status askorbat dengan terjadinya penghambatan secara kompetitif antara glukosa dan asam askorbat. Keduanya memiliki struktur hemologi yang sama dan secara bersama-sama menempati lokasi transportasi membran umum. ${ }^{29}$ Jika kadar glukosa darah meningkat berarti lebih sedikit vitamin $\mathrm{C}$ yang masuk ke dalam sel, sehingga kelebihan yang tidak digunakan dikeluarkan melalui urin. ${ }^{30}$

Dosis, durasi suplementasi, dan jumlah sampel bisa saja menjadi alasan suplementasi vitamin C 250 mg dan vitamin E 400 IU tidak mampu menurunkan kadar MDA setelah pemberian selama 6 minggu dan hal tersebut dapat menjadi faktor yang menggangu validitas eksternal pada penelitian ini. Beberapa penelitian menunjukkan hasil yang berbeda-beda terkait jumlah sampel, dosis, dan lama pemberian. Penelitian dengan dosis tunggal vitamin C $1000 \mathrm{mg}$ selama pemberian 6 minggu pada 15 orang kelompok perlakuan terbukti menurunkan kadar MDA pasien diabetes, ${ }^{22}$ dosis tunggal vitamin E 800 IU pada 13 orang kelompok perlakuan juga terbukti dapat menurunkan kadar MDA secara signifikan selama 6 minggu suplementasi, ${ }^{21}$ namun kedua penelitian tersebut menggunakan dosis tinggi. Penggunaan dosis tinggi dapat menyebabkan eritrolisis dan perubahan menjadi senyawa radikal di dalam tubuh. ${ }^{20,31}$ Penelitian oleh Neri et al menggunakan dosis kombinasi vitamin C $250 \mathrm{mg}$ dan vitamin E $300 \mathrm{~g}$ (447 IU) selama 15 hari pada 46 orang mampu menurunkan kadar MDA secara signifikan, namun penelitian ini menggunakan penambahan antioksidan lain yaitu $\mathrm{N}$-acetylcystein $(600 \mathrm{~g} / \mathrm{hari}) .^{32}$

Penelitian oleh Gariballa et al menggunakan vitamin C $167 \mathrm{mg}$ dan vitamin E $221 \mathrm{mg}$ (329,3 IU) dengan penambahan vitamin B kompleks selama 90 hari pada 50 orang kelompok suplementasi, tidak berpengaruh terhadap penurunan kadar MDA. ${ }^{33}$ Penelitian oleh Farvid et al (2005) yang salah satu kelompok penelitiannya diberikan vitamin C $200 \mathrm{mg}$ dan vitamin E 100 IU $(n=18)$ selama 90 hari menunjukkan tidak terdapat pengaruh terhadap penurunan kadar MDA pasien diabetes, namun kelompok penelitian yang diberikan vitamin C $200 \mathrm{mg}$; vitamin E $100 \mathrm{IU}$; magnesium (Mg) 200mg; dan seng (Zn) $30 \mathrm{mg}(\mathrm{n}=17)$ menunjukkan hasil bahwa terjadi penurunan kadar GDP $(p=0,035)$ dan penurunan kadar $\operatorname{MDA}(p=0,004){ }^{34}$

Penelitian yang memberikan vitamin $\mathrm{C}$ dan vitamin $\mathrm{E}$ ditambahkan dengan antioksidan lain seperti mineral magnesium dan seng menunjukkan hasil yang signifikan menurunkan kadar MDA. Aktivitas antioksidan enzimatik (SOD dan GSH) juga dipengaruhi oleh keberadaan logam mineral di dalam tubuh $(\mathrm{Fe}, \mathrm{Cu}, \mathrm{Zn}, \mathrm{Mn}$, dan $\mathrm{Mg}$ ) bersama vitamin $\mathrm{C}$, vitamin E, serta antioksidan non enzimatik lain (flavonoid dan Q10) dapat memutus rantai oksidasi dan menghambat produksi radikal bebas, salah satunya produksi MDA. ${ }^{24}$ Beberapa penelitian telah menunjukkan jumlah sampel, dosis, dan durasi yang bervariasi, memberikan hasil yang bervariasi pula terhadap penurunan kadar MDA pada pasien DMT2.

Kepatuhan subjek terkait waktu konsumsi vitamin $\mathrm{C}$ dan vitamin $\mathrm{E}$ bisa saja berdampak pada ketidakmampuan vitamin $\mathrm{C}$ dan vitamin $\mathrm{E}$ menurunkan kadar MDA. Beberapa subjek tidak mengkonsumsi suplemen vitamin sesuai anjuran, yaitu mengkonsumsi vitamin $C$ sebelum makan karena vitamin $C$ bekerja secara efektif disaat lambung kosong dan bekerja secara ekstraseluler dibawah 1 jam, dan konsusmsi vitamin $\mathrm{E}$ setelah makan, karena sifat vitamin $\mathrm{E}$ yang larut di dalam lemak. Beberapa subjek yang tidak mengikuti saran ini sehingga dapat berdampak pada tidak efektifnya kerja vitamin $\mathrm{C}$ dan vitamin $\mathrm{E}$ yang dikonsumsi.

Penelitian dilakukan bertepatan dengan bulan Ramadhan sehingga berpengaruh terhadap kadar glukosa darah, asupan makan, dan waktu pengambilan darah subjek yang berbeda-beda, bisa saja 
mempengaruhi hasil pemeriksaan. Alasan tersebut diluar kontrol peneliti dan menjadi keterbatasan dalam penelitian ini.

Saran untuk peneliti selanjutnya bahwa perlu dilakukan tindak lanjut penelitian terkait suplementasi vitamin $\mathrm{C}$ dan vitamin $\mathrm{E}$ dengan dosis dan durasi yang sama ditambahkan dengan antioksidan lain seperti mineral magnesium dan seng dan dikombinasikan dengan aktivitas fisik/olahraga diabetes secara rutin. Perlu pula dilakukan penelitian terhadap penurunan marker stres oksidatif seperti MDA, LDLox, atau NO dan pemeriksaan serum antioksidan SOD dan GSH pada pasien DMT2 untuk melihat pertahanan antioksidan tubuh dalam menghambat produksi radikal bebas dengan jumlah sampel yang lebih banyak dari penelitian sebelumnya dan tidak dilakukan pada bulan Ramadhan.

\section{SIMPULAN}

Kombinasi vitamin C $250 \mathrm{mg}$ dan vitamin E $400 \mathrm{IU}$ selama 6 minggu tidak menurunkan kadar MDA plasma, namun menghambat peningkatan kadar MDA plasma pasien DMT2.

\section{DAFTAR PUSTAKA}

1. American Diabetes Asssociation. Diabetes guidelines 2013, standard of medical care in diabetes. Diabetes Care. 2013;36(1):11-66.

2. Price S, Wilson LM. Patofisiologi: konsep klinis proses-proses penyakit. In: Pendit BU, editor. Jakarta: EGC; 2005.p.1259-73.

3. IDF. Diabetes atlas, $6^{\text {th }}$ edition. International Diabetes Federation. 2013.p.1-111.

4. Riskesdas. Riset kesahatan dasar: laporan nasional 2007. Badan Penelitian dan Pengembangan Departemen Kesehatan Republik Indonesia; 2008.p.1-291.

5. Riskesdas Sulawesi Selatan. Laporan hasil riset kesehatan dasar 2007, Provinsi Sulawesi Selatan. Badan Penelitian dan Pengembangan Kesehatan Departemen Kesehatan Republik Indonesia; 2008.p.1-217.

6. Karasu C. Glycoxidative stress and cardiovascular complications in experimentally induces diabetes: effects of antioxidant treatment. The Open Cardiovascular Medicine Journal. 2010;4:240-56.

7. Zatalia SR, Sanusi H. The role of antioxidant in the pathophysiology, complications, and management of diabetes mellitus. Acta Med Indones-Indones J Intern Med. 2013;45(2):141-7.

8. Setiawan B, Suhartono E. Stres oksidatif dan peran antioksidan pada diabetets melitus. Majalah Kedokteran Indonesia. 2005;55(2):86-91.
9. Hegde SV, Adhikari P, M N, D'Souza V. Effect of daily supplementation of fruits on oxidative stress indices and glyceamic status in type 2 diabetes mellitus. Complementary Therapies in Clinical Practice. 2013;19:97-100.

10.Gupta R, Sharma AK, Dobhal MP, Sharma MC, Gupta RS. Antidiabetic and antioxidant potential of b-sitosterol in streptozotocin-induced experimental hyperglycemia. Journal of Diabetes. 2011;3:29-37.

11. Slatter DA, Bolton CH, Bailey AJ. The Importance of lipid-derived malondialdehyde in diabetes mellitus. Diabetologia. 2000;43:550-7.

12.Dalle-Donne I, Rossi R, Colombo R, Giustarini D, Milzani A. Biomarkers of oxidative damage in human disease. Clinical Chemistry. 2006;52(4):601-23.

13. Shuda S, Prakash S. Lipid peroxidation and antioxidant status in south Indian patients with type 2 diabetes mellitus. IRJP. 2012;3(3):132-4.

14.Abou-Seif MA, Youssef AA. Evaluation of some biochemical changes in diabetic patients. Clinica Chimica Acta. 2004;346:161-70.

15.Mahboob M, Rahman MF, Grover P. Serum lipid peroxidation and antioxidant enzyme levels in male and female diabetic patients. SingmedJ. 2005;46(7):322-4.

16. Kalaivanam K, Dharmalingam M, Marcus S. Lipid peroxidation type 2 diabetes mellitus. Int J Diab Dev Ctries. 2006;26(1):30-2.

17.Pan HZ, Zhang L, Guo MY, Sui H, Li H, Wu WH, et al. The oxidative stress status in diabetets mellitus and diabetic nephropathy. Acta Diabetol. 2010;47(1):S71-S6.

18.Rafighi Z, Shiva A, Arab S, Yusuf RM. Association of dietary vitamin $\mathrm{C}$ and $\mathrm{E}$ intake antioxidant enzymes in type 2 diabetes mellitus patients. Global Journal of Health Science. 2013;5(3):183-7.

19. Dhakale GN, Chaudhari HV, Shrivastava M. Supplementation of vitamin $\mathrm{C}$ reduces blood glucose and improves glycosylated hemoglobin in type 2 diabetets mellitus: a randomized, doubleblind study. Advances in Pharmacological Sciences. 2011:1-5.

20.Muchtadi D. Antioksidan kiat sehat diusia produktif. Bandung: Alfabeta; 2013.p.40-89.

21.Ble-Castillo JL, Carmona-Diaz E, Mendez JD, Larios-Medina FJ, Median-Santillan R, ClevaVillanueva $\mathrm{G}$, et al. Effect of a-tocopherol on the metabolic control and oxidative stress in female type 2 diabetics. BIOPHA. 2005;59(6):290-5.

22.Mazloom Z, Hejazi N, Dabbaghmanesh MH, Tabatabei HR, Ahmadi A, Ansar H. Effect of vitamin $\mathrm{C}$ supplementation on postprandial oxidative stress and lipid profil in type 2 diabetic patients. PakJBiolSci. 2011;14(19):900-4. 
23. Nweke IN, Ohaeri OC, Ezeala CC. Effect of vitamin on malondialdehyde and glutathione levels in type 2 diabetic Nigerians. The Internet Journal of Nutrition and Wellness. 2009;7(2):1-4.

24.Winarsi H. Antioksidan alami dan radikal bebas. Yogyakarta: Kanisius; 2011.p.50-7,137-54.

25. Bandeira SdM, Guedes GdS, Fonseca LJSd, Pires AS, Gelain DP, Moreira JCF, et al. Characterization of blood oxidative stress in type 2 diabetes mellitus patients: increase in lipid proxidation and SOD activity. Hindawi Pubh Copr. 2012:1-13.

26. Savu O, Ionescu-Tirgoviste C, Atanasiu V, Gaman L, Papacocea R, Stoian I. Increase in total antioxidant capacity of plasma despite high levels of oxidative stress in uncomplicated type 2 diabetes mellitus. Journal of International Medical Research. 2012;40:709-16.

27.Rahimi R, Nikfar S, Larijani B, Abdollahi M. A review on the role of antioxidants in the management of diabetes and its complications. Biomedicine \& Pharmacotherapy. 2005;59:365-73.

28. Tjahjono K. Pengaruh pemberian asam lemak trans terhadap status inflamasi, stres oksidatif, dan kerusakan sel beta pankreas, studi eksperimental pada tikus sprague dawley. Disertasi. Semarang: Universitas Diponegoro; 2014.
29. Hisalkar P, Patne A, Fawade M. Assessment of plasma antioxidant levels in type 2 diabetes patients. Int J Biol Med Res. 2012;3(2):1796-800.

30.Pfaafly JR. Diabetes complication, hyperglicemia, and free radicals. Spring. 2001;77(1):1-18.

31.Linder MC. Biokimia nutrisi dan metabolisme dengan pemakaian secara klinis. Jakarta: UI Press; 2010.p.164-77, 201-15.

32.Neri S, Signorelli SS, Torrisi B, Pulvirenti D, Mauceri B, Abate G, et al. Effects of antioxidant supplementation on postprandial oxidative stress and endothelial dysfunction: a single-blind, 15-day clinical trial in patients with untreated type 2 diabetes, subject with impaired glucose tolerance, and healthy controls. Clinical Therapeutics. 2005;27(11):1764-73.

33. Gariballa S, Afandi B, Haltem MA, Yassin J, Habib $\mathrm{H}$, Ibrahim $\mathrm{W}$. Oxidative damage and inflammation in obese diabetic Emirati subjects supplemented with antioxidants and B-vitamins: a randomized placebo-controlled trail. Nutrition \& Metabolism. 2013;10(21):1-7.

34.Farvid MS, Jalali M, Siassi F, Hosseini M. Comparison of the effects of vitamins and/or mineral supplementation on glomerular and tubular dysfunction in type 2 diabetes. Diabetes Care. 2005;28(10):2458-64. 